\title{
BIOACTIVE TRITERPENES AND PHENOLICS OF LEAVES OF Eugenia brasiliensis
}

\author{
Michele Debiase Alberton Magina, Eduardo Monguilhot Dalmarco e Juliana Bastos Dalmarco \\ Departamento de Ciências Farmacêuticas, Universidade Regional de Blumenau, 89010-971 Blumenau - SC, Brasil \\ Guilherme Colla, Moacir Geraldo Pizzolatti e Inês Maria Costa Brighente* \\ Departamento de Química, Universidade Federal de Santa Catarina, CP 476, 88040-900 Florianópolis - SC, Brasil
}

Recebido em 10/10/11; aceito em 17/1/12; publicado na web em 15/5/12

\begin{abstract}
A chemical investigation of Eugenia brasiliensis Lam. (Myrtaceae) leaves led to the isolation of $\alpha$-amyrin and $\beta$-amyrin (in a mixture), betulin, 29-hydroxy-oleanolic acid, quercetin, catechin and gallocatechin. Herein, the identification of 29-hydroxy-oleanolic acid is reported for the first time in the Myrtaceae family. Moreover, in this study, the extract, fractions and six of the seven compounds were monitored for toxicity toward Artemia salina, antibacterial and acetylcholinesterase inhibitory activity. The crude ethanol extract of the leaves and fractions were found be active on A. salina toxicity bioassay.
\end{abstract}

Keywords: acetylcholinesterase; triterpenes; Eugenia brasiliensis.

\section{INTRODUCTION}

Eugenia is one of the 132 genera of the Myrtaceae family, with around 1000 species. It is the largest genus in the Myrtaceae family in Tropical America. ${ }^{1}$ Eugenia grows from Mexico and the Caribbean to Northern Argentina and it is estimated that 350 species are native from Brazil. ${ }^{2}$ The plants of this genus are evergreen trees or shrubs, with spherical fruit which is generally edible, ${ }^{3}$ for instance, Eugenia uniflora (Surinam cherry; known in Brazil as pitanga) and Eugenia edulis (known in Brazil as jaboticaba).

Species of the genus Eugenia show a variety of biological activities, such us antimicrobial, ${ }^{4}$ antioxidant, ${ }^{5}$ antidiabetic ${ }^{6}$ and anti-inflammatory activity. ${ }^{7}$ The compounds generally associated with this genus are flavonoids and triterpenoids, although chalcones ${ }^{8}$ and tannins ${ }^{9}$ are also present. Among the flavonoids, such as glycosides or aglycone, there is a predominance of polyhydroxylated flavanols. ${ }^{10}$ The majority of compounds isolated from these species ${ }^{11}$ are pentacyclic triterpenes with a lupane or oleanane skeleton.

Eugenia brasiliensis Lamarck (synonyms Eugenia bracteolaris, Eugenia dombeui, Stenocalyx brasiliensis) is a tree that grows in the Brazilian rainforests commonly known as grumixama. ${ }^{12}$ Traditionally, the leaves, fruit and bark of E. brasiliensis are used for gastrointestinal disorders, rheumatism, and as a diuretic. ${ }^{13}$ Ursolic acid has been isolated from the leaves of E. brasiliensis ${ }^{14}$ and anthocyanins, ellagic acid, myricetin, quercetin, quercitrin and rutin have also been detected in the fruits. ${ }^{15}$ Our studies have shown that the essential oil extracted from the leaves of E. brasiliensis has an appreciable antibacterial activity, ${ }^{16}$ while the crude hydroalcoholic extract of the leaves and fractions has anti-inflammatory activity. ${ }^{17}$

The use of a simple microorganism such as Artemia salina to test in vivo lethality can represent a simple tool for guiding the screening and fractionation of physiologically active plant extracts. It has been demonstrated that results on this test correlate reasonably well with cytotoxicity and other biological properties. ${ }^{18}$ There have been many reports on the use of Artemia salina for the general screening of natural or synthetic bioactive substances. ${ }^{19}$

Microorganisms are frequently the cause of prevailing diseases, presenting a serious public health issue for a significant segment of the population which is not adequately covered by either private or

*e-mail: ines@qmc.ufsc.br public health care systems. In recent years, multiple resistance in human pathogenic microorganisms has developed due to the indiscriminate use of commercial antimicrobial drugs commonly employed in the treatment of infectious diseases. This fact, together with the undesirable side effects of certain antibiotics, and the emergence of previously uncommon infections, has driven scientists to search for new antimicrobial substances from various sources, including medicinal plants. ${ }^{20}$

The inhibition of acetylcholinesterase, the key enzyme in the breakdown of acetylcholine, is one of the treatment strategies employed against several neurological disorders such as Alzheimer`s disease, senile dementia, ataxia, and myasthenia gravis. ${ }^{21}$ Acetylcholine is a compound liberated at the synaptic gap as a neurotransmitter. Neurotransmitter disturbances and insufficient cholinergic functions have been identified as pathological features in central nervous system disorders. The most important changes observed in the brain are a decrease in cortical levels of the neurotransmitter acetylcholine. Inhibition of acetylcholinesterase can therefore restore the level of acetylcholine in the brain. Medicinal plants have been used traditionally to enhance cognitive function and to alleviate other symptoms associated with Alzheimer's disease. ${ }^{22}$ Most of the drugs used in Alzheimer's therapy contain an enzyme inhibitor, e.g. galantamine. ${ }^{21}$

Few of the 350 native species of Eugenia have been studied from at phytochemical and biological point of view. In this context, the present paper reports a phytochemical study on E. brasiliensis leaves, describing the isolation and identification of triterpenes $\alpha$-amyrin (1) and $\beta$-amyrin (2) (in a mixture), betulin (3), 29-hydroxy-oleanolic acid (4), and the phenolic compounds quercetin (5), catechin (6) and gallocatechin (7). Compound $\mathbf{4}$ is described for the first time in the Myrtaceae family. The extract, fractions and compounds 1-3 and 5-7 were evaluated based on toxicity toward Artemia salina, as well as antibacterial and antiacetylcholinesterase activity.

\section{EXPERIMENTAL}

\section{General experimental procedures}

$1 \mathrm{D}$ and $2 \mathrm{D}{ }^{1} \mathrm{H},{ }^{13} \mathrm{C}$ NMR spectra were acquired on a Varian AS400 spectrometer, operating at $400 \mathrm{MHz}\left({ }^{1} \mathrm{H}\right)$ and $100 \mathrm{MHz}\left({ }^{13} \mathrm{C}\right)$ in $\mathrm{CDCl}_{3}$ or $\mathrm{CD}_{3} \mathrm{OD}$ or both solutions, with TMS as the internal standard.

The melting point of the isolated compounds was determined 
using the digital apparatus Micro Chemistry MQA PF-301. A Perkin Elmer FTIR 16 PC spectrometer was used to obtain the spectra in the infrared (IR) region using compressed tablets of $\mathrm{KBr}$ or $\mathrm{NaCl}$ film and values were recorded in $\mathrm{cm}^{-1}$. Optical rotation measurements were performed on a Schimidt-Haensch Polatronic E polarimeter (Berlin, Gemany).

GC analysis was carried out with a GC-14 B Series instrument (Shimatzu, Japan) equipped with a flame detector (FID) at $290{ }^{\circ} \mathrm{C}$. The chromatographic conditions were as follows: fused silica capillary column ( $30 \mathrm{~m} \times 0.25 \mathrm{~mm}$ ) with a DB-1; carrier gas $\mathrm{N}_{2}$; injector (split/ splitless); temperature $300{ }^{\circ} \mathrm{C}$.

Silica gel (70-230 mesh, Merck) was used for the column chromatography (CC) separations and silica gel $60 \mathrm{PF}_{254}$ (Merck) was used for analytical $(0.25 \mathrm{~mm})$ thin layer chromatography (TLC).

The solvent used in the liquid-liquid partitioning, column chromatography and thin-layer chromatography, as well as the reagents used for the biological assays, were of analytical grade.

Acetylthiocholine iodide (ATCI), 5,5'-dithiobis-[2-nitrobenzoic acid] (DTNB), acetylcholinesterase (AChE) type VI-S from electric eel, tris- $\mathrm{HCl}$ buffer (tris[hydroxymethyl]aminomethane), bovine serum albumin (BSA) and magnesium chloride hexahydrate were supplied by Sigma (USA). The bioassay was performed on a Perkin Elmer Lambda S spectrophotometer.

\section{Plant material}

The leaves of E. brasiliensis Lam. were collected in Santo Amaro da Imperatriz (SC), Brazil. A voucher specimen was identified by Prof. Dr. D. de B. Falkenberg and deposited in the Universidade Federal de Santa Catarina Herbarium under number FLOR-34675.

\section{Extraction and isolation}

The leaves $(1.5 \mathrm{~kg})$ were powdered and extracted with $96 \%$ ethanol by maceration at room temperature for 7 days. After filtration, the ethanol extract was further evaporated to dryness at $45^{\circ} \mathrm{C}$ under reduced pressure, yielding the crude ethanol extract (170 g). This extract was redissolved in a mixture of $\mathrm{MeOH}: \mathrm{H}_{2} \mathrm{O}(3: 7 \mathrm{v} / \mathrm{v})$ to yield an insoluble fraction $(45.3 \%)$. The solution obtained after filtration was partitioned successively with solvents of increasing polarity to give hexane $(17.9 \%)$ dichloromethane $(9.1 \%)$ and ethyl acetate $(19.6 \%)$ fractions.

The non-soluble material (5.0 g) was chromatographed on silica gel using hexane/EtOAc mixtures with increasing polarity yielding 31 fractions $(100 \mathrm{~mL})$, which were combined in sub-fractions according to TLC analysis. The sub-fraction 13-15 (hex/AcOEt 90\%) yielded a mixture of triterpenes (143 mg), $\alpha$-amyrin (1) and $\beta$-amyrin (2). Sub-fraction 21-23 (hex/AcOEt 75\%) was recrystallized with $\mathrm{CHCl}_{3} /$ $\mathrm{MeOH}$ 1:1, yielding betulin (3) (35 mg).

The dichloromethane fraction $(13.0 \mathrm{~g})$ was also chromatographed in a silica gel column applying the same conditions employed for the non-soluble fraction. Sub-fractions 4-9 (hex/AcOEt 80\%) and 16 (hex/AcOEt 60\%), after observation by TLC, led to the isolation of $510 \mathrm{mg}$ of betulin (3) and $15 \mathrm{mg}$ of mesembryanthemoidigenic acid or 29-hydroxy-oleanolic acid (4), respectively.

The ethyl acetate fraction (12.0 g) was first chromatographed in a silica gel column with hexane containing increasing amounts of EtOAc. A total of 34 fractions were obtained from this column. The fraction 20-22 (hex/AcOEt 5\%) obtained from this column was submitted to CC again by using a mixture of hex/AcOEt $20 \%$ and increasing the polarity up to EtOH $100 \%$, giving 34 fractions. The sub-fraction 3-4 (AcOEt/EtOH 20\%) yielded compound 5 as an amorphous yellow powder, denominated quercetin $(40 \mathrm{mg})$. The sub-fraction 13-16 (AcOEt/EtOH 10\%) afforded $150 \mathrm{mg}$ of pale yellow solid denominated catechin (6). The sub-fraction 22-24 (AcOEt/EtOH 5\%) was further subjected to silica gel CC eluted with AcOEt $100 \%$, increasing the polarity up to EtOH $100 \%$. Among 26 fractions, the fraction 15-17 (AcOEt/EtOH 1\%) afforded $142 \mathrm{mg}$ of a light yellow solid denominated gallocatechin (7).

The structural characteristics of the compounds were determined by the spectroscopic methods of infrared spectroscopy, ${ }^{1} \mathrm{H}$ and ${ }^{13} \mathrm{C}$ nuclear magnetic resonance, with the aid of two dimensional techniques and by comparing the experimental data with those described in the literature.

\section{Compounds 1 and 2}

$\alpha$ and $\beta$-amyrin, white amorphous powder, p.f. $184.9-187.4{ }^{\circ} \mathrm{C}$. IR (KBr) $v_{\max } \mathrm{cm}^{-1}: 3390(-\mathrm{OH}), 2942(-\mathrm{CH}), 1644(\mathrm{C}=\mathrm{C})$. These compounds were identified after comparison of the physical chemical data with data available in the literature. ${ }^{23,24}$

\section{Compound 3}

Betulin or 3ß,28-dihydroxy-lup-20(29)-ene, white crystals (re-

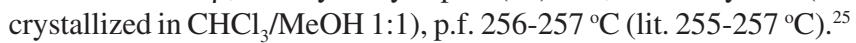
IR (KBr) $v_{\max } \mathrm{cm}^{-1}: 3399(-\mathrm{OH}), 2941(-\mathrm{CH}), 1639(\mathrm{C}=\mathrm{C})$. Identified by co-TLC with an authentic sample and by combination methods (IR, ${ }^{1} \mathrm{H}$ NMR, ${ }^{13} \mathrm{CNMR}$ spectra) and comparison with literature data. ${ }^{24,25}$

\section{Compound 4}

Mesembryanthemoidigenic acid or 3 $\beta, 29$-dihydroxy-olean12-en-28-oic acid, white powder (recrystallized in $\mathrm{CHCl}_{3} / \mathrm{MeOH}$ 1:1), p.f. 306.4-308.5 ${ }^{\circ} \mathrm{C}$ (lit. $\left.305-309^{\circ} \mathrm{C}\right){ }^{26} \mathrm{IR}(\mathrm{KBr}) v_{\max } \mathrm{cm}^{-1}: 3420$ $(-\mathrm{OH}), 2954(-\mathrm{CH}), 1636(\mathrm{C}=\mathrm{C}) .{ }^{1} \mathrm{H}$ NMR $\delta\left(400 \mathrm{MHz}, \mathrm{CDCl}_{3}: 0.77\right.$ $(s, 3 \mathrm{H}, \mathrm{H}-30), 0.81$ (s, 3H, H-25), 0.93 ( $s, 3 \mathrm{H}, \mathrm{H}-26), 0.94(s, 6 \mathrm{H}$, $\mathrm{H}-23$ and H-24), 1.17 ( $s, 3 \mathrm{H}, \mathrm{H}-27), 3.18$ ( $s, 2 \mathrm{H}, \mathrm{H}-29), 3.37$ ( $m, 1 \mathrm{H}$, $\mathrm{H}-3), 5.25$ ( $t, 1 \mathrm{H}, \mathrm{H}-12) .{ }^{13} \mathrm{C}$ NMR $\delta\left(100 \mathrm{MHz}, \mathrm{CDCl}_{3}\right): 180.0(\mathrm{C}-$ 28), 143.9 (C-13), 122.6 (C-12), 78.5 (C-3), 73.2 (C-29), 55.6 (C-5), 46.7 (C-9), 46.4 (C-17), 41.6 (C-14), 40.7 (C-18), 40.2 (C-19), 39.3 (C-8), 38.7 (C-4), 38.6 (C-1), 37.9 (C-22), 36.9 (C-10), 35.6 (C-20), 32.8 (C-7), 29.5 (C-21), 28.1 (C-23), 27.6 (C-15), 27.5 (C-2), 25.2 (C-27), 23.3 (C-11), 22.9 (C-16), 18.3 (C-6 e C-30), 16.5 (C-26), 15.1 (C-24), 14.7 (C-25). Supplementary material.

\section{Compound 5}

Quercetin or 3,5,7,3',4'-pentahydroxyflavone, light yellow solid, p.f. $304-307{ }^{\circ} \mathrm{C}$ (lit. $\left.310-312{ }^{\circ} \mathrm{C}\right){ }^{27} \mathrm{IR}(\mathrm{KBr}) v_{\max } \mathrm{cm}^{-1}: 3410(-\mathrm{OH})$, $1693(\mathrm{C}=\mathrm{O})$. Identified by co-TLC with an authentic sample $(R f=$ 0.6 , hexane/AcOEt 6:4) and by comparing the spectroscopic data with those available in the literature. ${ }^{28}$

\section{Compound 6}

Catechin or (+)-(2R,3S)-5,7,3',4'-tetrahydroxyflavan-3-ol, pale yellow solid, p.f. $165.4-172.5^{\circ} \mathrm{C}$ (lit. $\left.175-187^{\circ} \mathrm{C}\right) .{ }^{29}[\alpha]^{25}{ }_{\mathrm{D}}=+13^{\circ}, 0.4$ in $50 \%$ aqueous acetone. IR $(\mathrm{KBr}) v_{\max } \mathrm{cm}^{-1}: 3386 \mathrm{~cm}^{-1}(-\mathrm{OH}), 1615$ $(\mathrm{C}=\mathrm{C}), 1142(\mathrm{C}-\mathrm{O}) .{ }^{1} \mathrm{H}$ NMR $\delta$ (400 MHz, CD $\mathrm{OD}: 2.38\left(d d, J_{1}=\right.$ 16.0 and $\left.J_{2}=7.9 \mathrm{~Hz}, 1 \mathrm{H}_{\mathrm{ax}}, \mathrm{H}-4\right), 2.68\left(d d, J_{1}=16.0\right.$ and $J_{2}=5.2 \mathrm{~Hz}$, $\left.1 \mathrm{H}_{\mathrm{eq}}, \mathrm{H}-4\right), 3.86(m, \mathrm{H}-3), 4.56\left(d, J_{l}=7.6 \mathrm{~Hz}, 1 \mathrm{H}, \mathrm{H}-2\right), 5.82(d, J=$ $1.6,1 \mathrm{H}, \mathrm{H}-8), 5.91(d, J=1.6,1 \mathrm{H}, \mathrm{H}-6), 6.63\left(d d, J_{1}=8.0\right.$ and $J_{2}=$ $\left.1.6,1 \mathrm{H}, \mathrm{H}-6^{\prime}\right), 6.66$ ( $\left.d, J=8.0,1 \mathrm{H}, \mathrm{H}-5^{\prime}\right), 6.74\left(d, J=1.6,1 \mathrm{H}, \mathrm{H}-2^{\prime}\right)$.

\section{Compound 7}

Gallocatechin or (+)-(2R,3S)- 5,7,3',4',5'-pentahydroxyflavan3-ol, light yellow solid, p.f. $225.0-228.3{ }^{\circ} \mathrm{C}$ (lit. 189-191 $\left.{ }^{\circ} \mathrm{C}\right) \cdot{ }^{30}[\alpha]^{25}{ }_{\mathrm{D}}=$ $+17^{\circ}, 0.4$ in methanol. IR $(\mathrm{KBr}) v_{\max } \mathrm{cm}^{-1}: 3564(-\mathrm{OH}), 1621(\mathrm{C}=\mathrm{C})$, 1159 (C-O). ${ }^{1} \mathrm{H}$ NMR $\delta\left(400 \mathrm{MHz}, \mathrm{CD}_{3} \mathrm{OD}: 2.53\right.$ (dd, $J_{1}=16.0$ and $\left.J_{2}=7.65 \mathrm{~Hz}, 1 \mathrm{H}_{\mathrm{ax}}, \mathrm{H}-4\right), 2.79\left(d d, J_{1}=16.0\right.$ and $J_{2}=5.6 \mathrm{~Hz}, 1 \mathrm{H}_{\mathrm{eq}}$, 
H-4), 3.89 ( $m, \mathrm{H}-3), 4.52\left(d, J_{1}=6.8 \mathrm{~Hz}, 1 \mathrm{H}, \mathrm{H}-2\right), 5.83(d, J=2.4$, $1 \mathrm{H}, \mathrm{H}-8), 5.94$ ( $d, J=2.4,1 \mathrm{H}, \mathrm{H}-6), 6.45$ ( $s, \mathrm{H}-2$ ' and H-6').

\section{Artemia salina lethality test}

The toxic effect of the plant extract and its fractions against Artemia salina nauplii was tested according to the method of Sam ${ }^{31}$ with minor modifications. Dried A. salina eggs were hatched in illuminated artificial seawater at $25{ }^{\circ} \mathrm{C}$. After $48 \mathrm{~h}$ incubation, $1000 \mu \mathrm{L}$ of seawater containing $1 \%$ Tween $20(\mathrm{v} / \mathrm{v})$ and 7-10 free-swimming nauplii was separately transferred to 24-well flat-bottomed tissue culture plates. Toxicities of the extract and fractions were tested at several concentrations $\left(10-1000 \mu \mathrm{g} \mathrm{mL}^{-1}\right)$. Three replicates were used for each concentration. The culture plates were incubated as described above and the number of dead nauplii were counted after 24 h. Potassium dichromate $\left(\mathrm{K}_{2} \mathrm{Cr}_{2} \mathrm{O}_{7} ; \mathrm{LC}_{50} \sim 20-40 \mu \mathrm{g} \mathrm{mL}^{-1}\right)$ and seawater solution with $1 \%$ Tween $20 \mathrm{v} / \mathrm{v}$ were used as positive and negative controls, respectively. The lethal concentrations which led to $50 \%$ mortality $\left(\mathrm{LC}_{50}\right)$ with $95 \%$ confidence intervals were determined using the probit method. $\mathrm{LC}_{50}$ values were taken as the measure of toxicity of the extract or fractions. $\mathrm{LC}_{50}$ values greater than $1000 \mu \mathrm{g}$ $\mathrm{mL}^{-1}$ for the plant extract and the fractions were considered inactive.

\section{Antibacterial assays}

Tests were performed on Staphylococcus aureus (ATCC 25923), Escherichia coli (ATCC 25922) and Pseudomonas aeruginosa (ATCC 27853) acquired from The American Type Culture Collection (ATCC). All organisms were maintained in brain-heart infusion (BHI) medium containing $30 \%$ (v/v) glycerol at $20^{\circ} \mathrm{C}$. Before testing, the suspensions were transferred to trypticase soy agar supplemented with 5\% of sheep blood (Difco) and aerobically grown overnight at $35{ }^{\circ} \mathrm{C}$. The inocula were prepared by adjusting the turbidity of the suspension to match the $0.5 \mathrm{McF}$ arland standard in saline solution $(0.9 \%)$. The broth microdilution method was used to determine the MIC (minimum inhibitory concentration) of the samples obtained from Eugenia brasiliensis against the test organisms as recommended by the National Committee for Clinical Laboratory Standards. ${ }^{32}$ This test was performed in sterile 96-well microplates. The samples were properly prepared and transferred to each microplate well in order to obtain a two-fold serial dilution of the original extract (from 1:2 to $1: 256$ starting from the concentration of $50 \mathrm{mg} \mathrm{mL}^{-1}$ ). The inocula $(100 \mu \mathrm{L})$ containing $5 \times 10^{5} \mathrm{CFU}$ of each microorganism, were added to each well. A number of wells were reserved in each plate for sterility control (no inoculum added), inoculum viability (no extract added), and to assess the inhibitory effect of ethanol. Plates were aerobically incubated at $35^{\circ} \mathrm{C}$. After incubation for $18-24 \mathrm{~h}$, bacterial growth was evaluated by the presence of turbidity and a pellet on the well bottom. MIC was defined as the lowest concentration of samples that had no macroscopically visible growth. Each experiment was repeated at least twice.

\section{Acetylcholinesterase inhibition}

The enzymatic activity was measured using an adaptation of the method described by Mata et al. ${ }^{33}$ Briefly, $325 \mu \mathrm{L}$ of $50 \mathrm{mM}$ Tris-HCl buffer, $\mathrm{pH} 8,100 \mu \mathrm{L}$ of a buffer solution of sample $(0.1$ $\mathrm{mg} \mathrm{mL}^{-1}$ for the extract and fractions, and $0.01 \mathrm{mg} \mathrm{mL}^{-1}$ for isolated compounds, dissolved in EtOH) and $25 \mu \mathrm{L}$ of acetylcholinesterase (AchE) solution containing $0.28 \mathrm{U} / \mathrm{mL}$ (50 mM Tris- $\mathrm{HCl}$, pH 8 buffer, $0.1 \% \mathrm{BSA}$ ) were incubated for $15 \mathrm{~min}$. Subsequently, $75 \mu \mathrm{L}$ of a solution of ACTI $\left(0.023 \mathrm{mg} \mathrm{mL}^{-1}\right.$ in water $)$ and $475 \mu \mathrm{L}$ of DTNB ( $3 \mathrm{mM}$ in Tris- $\mathrm{HCl}$, $\mathrm{pH} 8$ buffer, $0.1 \mathrm{M} \mathrm{NaCl}, 0.02 \mathrm{M} \mathrm{MgCl}_{2}$ ) were added and the final mixture incubated for another $30 \mathrm{~min}$ at room temperature. Absorbance of the mixture was measured at $405 \mathrm{~nm}$. A control mixture was prepared, using $100 \mu \mathrm{L}$ of a solution similar to the sample mixture but with ethanol instead of sample, and was considered as $100 \%$ activity of AchE. Inhibition (\%) was calculated as follows: $\mathrm{I}(\%)=100-\left(\mathrm{A}_{\text {sample }} / \mathrm{A}_{\text {control }}\right) \times 100$, where $\mathrm{A}_{\text {sample }}$ is the absorbance of the sample containing the reactant and $\mathrm{A}_{\text {control }}$ the $\mathrm{ab}$ sorbance of the reaction control. Tests were carried out in triplicate and a blank with Tris-HCl buffer instead of enzyme solution was used. The sample concentration providing $50 \%$ inhibition $\left(\mathrm{IC}_{50}\right)$ was obtained by plotting the inhibition percentage against the sample solution concentrations. Reminyl containing galantamine was used as the positive control.

\section{RESULTS AND DISCUSSION}

The non-soluble, dichloromethane and ethyl acetate fractions obtained from the leaves of E. brasiliensis after chromatographic fractionation afforded four triterpenes (1-4), one flavonol (5), and two catechins (6-7).
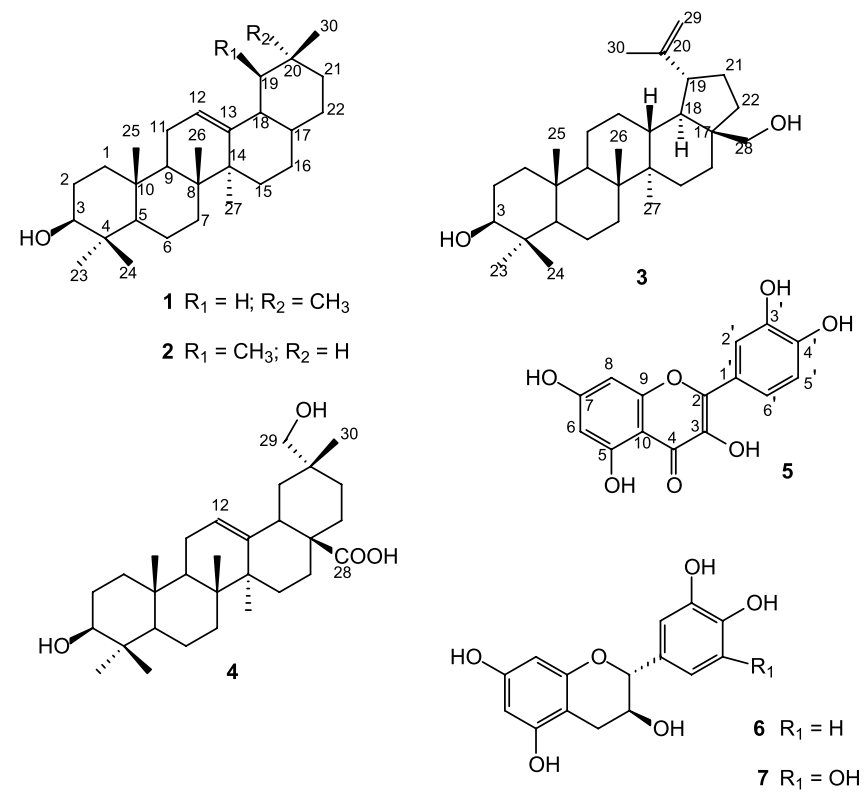

Figure 1. Structures of compounds isolated from Eugenia brasiliensis

Compounds $\mathbf{1}$ and $\mathbf{2}$ were identified as a mixture of $\alpha$-amyrin (1) and $\beta$-amyrin (2). ${ }^{23,24}$ Comparison of the sample with a standard mixture of $\alpha$ - and $\beta$-amyrin by gas chromatography confirmed the presence of these two structures $(\beta$-amyrin $\operatorname{Tr}=19.1 \mathrm{~min}$ and $\alpha$-amyrin $\operatorname{Tr}=20.7 \mathrm{~min}$ ), and the $\beta$-amyrin was found in greater quantity, at a ratio of 3:1. Retention times were similar to those observed when these triterpenes were analyzed in mixture. ${ }^{34}$ The ${ }^{1} \mathrm{H}$ and ${ }^{13} \mathrm{C}$ NMR spectra of compound $\mathbf{3}$ confirmed the structure of betulin $(\mathbf{3}) .^{24,25}$ For triterpene 4, in addition to six singlets for methyl groups ( $\mathrm{H}-23$, $\mathrm{H}-24, \mathrm{H}-25, \mathrm{H}-26, \mathrm{H}-27$ and $\mathrm{H}-30)$, signals for oxymethine hydrogen at $\delta 3.2(s, 2 \mathrm{H}, \mathrm{H}-29)$ and $3.4(m, 1 \mathrm{H}, \mathrm{H}-3)$ and olefinic hydrogens at $\delta 5.2(t, 1 \mathrm{H}, \mathrm{H}-12)$ were also observed. The ${ }^{13} \mathrm{C} \mathrm{NMR}$ spectrum of triterpene $\mathbf{4}$ showed, in addition, the six signals for $\mathrm{C}-\mathrm{sp}^{3}$, and signals for olefinic carbons, consistent with the presence of triterpene type olean-12-ene at $\delta 122.6(\mathrm{C}-12)$ and $143.9(\mathrm{C}-13)$. Also, signals at $\delta$ $78.5(\mathrm{CH})$ and $73.2\left(\mathrm{CH}_{2}\right)$ were observed, characteristic of oxymethine carbon at C-3 and C-29, respectively. Moreover, the signal observed at $\delta 180.0$ corresponded to a carbonyl group (C-28). Comparison of the chemical displacements of the NMR spectra of compound $\mathbf{4}$ with 
data available in the literature ${ }^{24,35}$ allowed the unequivocal identification of this structure as 29-hydroxy-oleanolic acid (4). There are no previous reports of the isolation or identification of this compound in the Myrtaceae family.

Comparison of the ${ }^{1} \mathrm{H}$ and ${ }^{13} \mathrm{C}$ NMR spectra for compound 5 with data available in the literature allowed the structure to be identified as quercetin. ${ }^{28}$ Catechin (6) and gallocatechin (7) were first identified by co-TLC with an authentic sample $(6: R f=0.6$, hexane/AcOEt 3:1 and 7: $R f=0.72$, hexane/AcOEt 1:3) and by comparison of their physicochemical data with those of the literature..$^{29,30}$ The NMR data were compared with those available in the literature, ${ }^{29,36}$ confirming the structure of compound $\mathbf{6}$ and $\mathbf{7}$ as catechin and gallocathechin, respectively.

The crude extract, fractions and isolated compounds of E. brasiliensis were evaluated for A. salina toxicity, as well as antibacterial and antiacetylcholinesterase activities. 29-Hydroxy-oleanolic acid (4) was obtained with low yield, and thus this compound was not submitted to the bioassays.

The results for the A. salina lethality of the samples are shown in Table 1. The crude extract and all of the fractions studied showed toxicity toward A. salina nauplii at concentrations $<1000 \mu \mathrm{g} \mathrm{mL}^{-1}$, but the ethyl acetate fraction was the most larvicidal sample, with an $\mathrm{LC}_{50}$ value of $788.9 \mu \mathrm{g} \mathrm{mL}^{-1}$.

Table 1 shows the results for the antibacterial activity obtained for the samples tested. For extracts or fractions which had MIC values below $0.1 \mathrm{mg} \mathrm{mL}^{-1}$, antibacterial activity was considered excellent, from 0.1 to $0.5 \mathrm{mg} \mathrm{mL}^{-1}$, moderate, from 0.5 to $1.0 \mathrm{mg} \mathrm{mL}^{-1}$ weak, and over $1 \mathrm{mg} \mathrm{mL}^{-1}$ inactive. ${ }^{37}$ For the isolated compounds, at an MIC value below $0.01 \mathrm{mg} \mathrm{mL}^{-1}$ the antibacterial activity was considered excellent, from 0.01 to $0.1 \mathrm{mg} \mathrm{mL}^{-1}$ good, and over $0.1 \mathrm{mg} \mathrm{mL}^{-1}$ inactive..$^{38}$ On the MIC assay, some vegetal samples showed activity against $E$. coli and $P$. aeruginosa. On the other hand, neither the crude extract nor the fractions tested showed activity against Staphylococcus aureus, a Gram-positive bacterium. The crude extract and fractions were especially active against Escherichia coli, a Gram-negative bacterium. The ethyl acetate fraction was the most active, showing moderate activity, with an MIC value of $0.39 \mathrm{mg} \mathrm{mL}^{-1}$, for this bacterium. The crude extract and dichloromethane fraction exhibited weak activity against Escherichia coli, with an MIC value of $0.78 \mathrm{mg}$
$\mathrm{mL}^{-1}$. Another finding was that the ethyl acetate fraction and crude extract showed weak activity against Pseudomonas aeruginosa, a Gram-negative bacteria, with an MIC value of $0.78 \mathrm{mg} \mathrm{mL}^{-1}$. This finding is interesting because the great majority of plant extracts are more active against Gram-positive than Gram-negative bacteria. The greater resistance of gram-negative bacteria to plant extracts has been previously reported. ${ }^{37}$ This resistance can be explained by the fact that the outer membrane of Gram-negative bacteria is known to present a barrier to many substances, including antibiotics, and the periplasmatic space contains enzymes that are able to breakdown foreign molecules. Moreover, Gram-negative bacteria have efflux pumps that reduce the cellular levels of antibiotics. ${ }^{39}$ Among the isolated compounds, only quercetin obtained from the AcOEt fraction showed good activity for all bacteria tested. Thus, quercetin may be responsible for the observed activity of the AcOEt fraction, especially against Gram-negative bacteria.

As summarized in Table 1, all of the vegetal samples exhibited inhibitory activity between 6.7 and $63.0 \%$ at a concentration of 0.1 $\mathrm{mg} \mathrm{mL} \mathrm{m}^{-1}$ for the AchE. The best inhibitory activity was recorded for the non-soluble fraction (63.9\%). Quercetin was the most active compound, with $35.0 \%$ inhibition of AchE at a concentration 0.01 $\mathrm{mg} \mathrm{mL}^{-1}$. There is a relatively lower number of reports on AChE inhibitory activity of flavonoids, which is the main strategy for the treatment of Alzheimer's Disease. On the other hand, flavonoids as the polyphenolic substances have been known to exhibit strong antioxidant activity, which is an advantage in Alzheimer's disease treatment. ${ }^{22}$ Previous studies have shown the value of diverse flavonoid derivatives for their $\mathrm{AChE}$ inhibitory effect at a concentration of $1 \mathrm{mg} / \mathrm{mL},{ }^{40}$ and amongst these, quercetin was found to be the most active against AChE, having 76.2\% inhibition. ${ }^{41}$ Docking studies have shown that quercetin binds through strong hydrogen bonds to several important amino acid residues of the enzyme. Hydrophobic interactions could also explain the potency of quercetin for inhibiting AChE. ${ }^{42}$ In evaluating the anti AChE activity of extracts and isolated compounds, the extracts and fractions were found to show better inhibition than the isolated substances. This fact is probably due to the presence of other active compounds in the extract, not isolated in the process of fractionation. Another explanation for this finding may be the synergistic effect commonly presented by medicinal plants. ${ }^{43}$

Table 1. Biological activity for the extract, fractions and compounds obtained from Eugenia brasiliensis

\begin{tabular}{|c|c|c|c|c|c|}
\hline Sample & $\begin{array}{c}\text { S. aureus } \\
\text { MIC } \\
\left(\mathrm{mg} \mathrm{mL}^{-1}\right)\end{array}$ & $\begin{array}{c}\text { E. coli } \\
\text { MIC } \\
\left(\mathrm{mg} \mathrm{mL}^{-1}\right)\end{array}$ & $\begin{array}{c}\text { P. aeruginosa } \\
\text { MIC } \\
\left(\mathrm{mg} \mathrm{mL}^{-1}\right)\end{array}$ & $\begin{array}{c}\text { A. salina } \\
\mathrm{LC}_{50}\left(\mu \mathrm{g} \mathrm{mL} \mathrm{mL}^{-1}\right)\end{array}$ & $\begin{array}{c}\text { AchE } \\
\% \text { inhibition }\end{array}$ \\
\hline Crude extract & 6.25 & 0.78 & 0.78 & $\begin{array}{c}807.2 \\
738.6-1060.2\end{array}$ & $40.3 \pm 0.1$ \\
\hline Non-soluble Fraction & 6.25 & 6.25 & 6.25 & $\begin{array}{c}885.1 \\
738.6-1060.2\end{array}$ & $63.0 \pm 0.2$ \\
\hline Dichloromethane Fraction & 3.12 & 0.78 & 6.25 & $\begin{array}{c}816.6 \\
738.6-1060.2\end{array}$ & $44.0 \pm 0.2$ \\
\hline Ethyl acetate Fraction & 1.56 & 0.39 & 0.78 & $\begin{array}{c}788.9 \\
738.6-1060.2\end{array}$ & $50.0 \pm 0.1$ \\
\hline$\alpha, \beta$-amyrin & 0.25 & 0.25 & 0.12 & -- & $6.7 \pm 0.1$ \\
\hline Betulin & 0.25 & 0.25 & 0.25 & -- & N.O. \\
\hline Quercetin & 0.05 & 0.10 & 0.10 & -- & $35.0 \pm 0.4$ \\
\hline Catechin & 0.30 & 0.30 & 0.30 & -- & N.O. \\
\hline Gallocatechin & 0.20 & 0.40 & 0.40 & -- & N.O. \\
\hline Positive control $^{\mathrm{a}}$ & 0.0001 & 0.0004 & 0.0004 & 25.0 & $82.7 \pm 0.3$ \\
\hline
\end{tabular}

${ }^{\mathrm{a}}$ gentamycin, for antibacterial assay; $\mathrm{K}_{2} \mathrm{Cr}_{2} \mathrm{O}_{7}$, for brine shrimp lethality; galantamine for acetylcholinesterase assay; -- not tested; N.O. not observed. 


\section{CONCLUSIONS}

The phenolic and triterpene compounds isolated from E. brasiliensis are consistent with biosynthetic routes and with results of phytochemical studies on plants of the genus Eugenia, verifying the taxonomic position of this species. The compounds isolated have not been previously reported for the species under study and, of the substances isolated, 29-hydroxy-oleanolic acid (4) was found for the first time in the Myrtaceae family.

The results obtained in this study point to the presence of active compounds, especially in the case of the ethyl acetate fraction (the most active fraction) where this may represent a valuable source of novel anti-infectious agents, particularly those active against Gramnegative bacteria.

\section{SUPPLEMENTARY MATERIAL}

Available at http://quimicanova.sbq.org.br, in the form of a PDF file with free access.

\section{ACKNOWLEDGMENTS}

We are grateful to $\mathrm{CNPq}$ to the financial support.

\section{REFERENCES}

1. Govaerts, R.; Sobral, M.; Ashton, P.; Barrie, F.; Holst, B. K.; Landrum, L. R.; Matsumoto, K.; Mazine, F. F.; Lughadha, E. N.; Proença, C.; Soares-Silva, L. H.; Wilson, P. G.; Lucas, E.; World Checklist of Myrtaceae, Royal Botanic Garden: Kew, 2008.

2. Landrum, L. R.; Kawasaki, M. L.; Brittonia 1997, 49, 508.

3. Auricchio, M.; Bacchi, E. M.; Rev. Inst. Adolfo Lutz 2003, 62, 55.

4. Dzamic, A.; Sokovic, M.; Ristic, M.S.; Grijic-Jovanovic, S.; Vukojevic, J.; Marin, P. D.; Chem. Nat. Comp. 2009, 45, 269; Machado, K. E.; Cechinel Filho, V.; Tessarolo, R.; Mallmann, C.; Meyre-Silva, C.; Bella Cruz, A.; Pharm. Biol. 2005, 43, 636.

5. Gülçin, I.; Beydemir, G. S. S.; Elmasta, M.; Küfrevioglu, Ö.; Food Chem. 2004, 87, 393; Ravi, K.; Ramachandran, B.; Subramanian, S.; Life Sci. 2004, 75, 2717; Magina, M. D. A.; Gilioli A.; Moresco H. H.; Colla, G.; Pizzolatti, M. G.; Brighente, I. M. C.; Latin Am. J. Pharm. 2010, 29, 376.

6. Sharma, S. B.; Nasir, A.; Prabhu, K. M.; Murthy, P. S.; J. Ethnopharmacol. 2006, 104, 367; Sharma, B.; Viswanath, G.; Salunke, R.; Roy, P.; Food Chem. 2008, 110, 697; Vikrant, V.; Grover, J. K.; Tandon, N.; Rathi, S. S.; Gupta, N.; J. Ethnopharmacol. 2001, 76, 139.

7. Magina, M. D. A.; Pietrovski, E. F.; Gomig, F.; Falkenberg, D. B.; Cabrini, D. A.; Otuki, M. F.; Pizzolatti, M. G.; Brighente, I. M. C.; Braz. J. Pharm. Sci. 2009, 45, 171; Ávila-Penã, D.; Penã, N.; Quintero, L.; Suárez-Roca, H.; J. Ethnopharmacol. 2007, 112, 380.

8. Simirgiotis, M. R.; Adachi, S.; To, S.; Yang, H.; Reynertson, K. A.; Basile, M. J.; Gil, R. R.; Weinstein, I. B.; Kennelly, E. J.; Food Chem. 2008, 107, 813.

9. Yang, L. L.; Lee, C. Y.; Yen, K. Y.; Cancer Lett. 2000, 157, 65.

10. Hussein, S. A. M.; Hashem, A. N. M.; Selien, M. A.; Lindequist, U.; Nawwar, M. A. M.; Phytochemistry 2003, 64, 883.

11. Gu, J. Q.; Park, E. J.; Luyengi, L.; Hawthorne, M. E.; Mehta, R. G.; Farnsworth, N. R.; Pezzuto, J.M.; Kinghorn, A. D.; Phytochemistry 2001, 58, 121.

12. Fischer, D. C. H.; Limberger, R. P.; Henriques, A. T.; Moreno, P. R. H.; J. Essent Oil Res. 2005, 17, 499.

13. Revilla, J.; Plantas úteis da Bacia Amazônica, Inpa: Rio de Janeiro, 2002, vol. 44.

14. Frighetto, N.; Welendorf, R. M.; Silva, A. M. P.; Nakamura, M. J.; Siani, A. C.; Rev. Bras. Farmacog. 2005, 15, 338.
15. Reynertson, K. A.; Yang, H.; Jiang, B.; Basile, M. J.; Kennely, E. J.; Food Chem. 2008, 109, 883.

16. Magina, M. D. A.; Dalmarco, E. M.; Wisniewski, A.; Simionatto, E. L.; Dalmarco, J. B. ; Pizzolatti, M. G.; Brighente, I. M. C.; J. Nat.Med. 2009, 63, 345.

17. Pietrovski, E. F.; Magina, M. D. A.; Gomig, F.; Plietrovski, C. F.; Micke, G. A.; Barcellos, M.; Pizzolatti, M. G.; Cabrini, D. A.; Brighente, I. M. C.; Otuki, M. F.; J. Pharm. Pharmacol. 2008, 60, 479.

18. McLaughlin J. L. In Methods in Plant Biochemistry; Hostettmann, K., ed.; Academic Press: London, 1991, vol. 6.

19. Luna, J. S.; Santos, A. F.; Lima, M. R. F.; Omena, M. C.; Mendonça, F. A. C.; Bieber, L. W.; Sant'Ana, A. E. G.; J. Ethnopharmacol. 2005, 97, 199; Dos Santos, A. F.; Cavada, B. S.; Rocha, B. A. M.; Nascimento, K. S.; Sant'Ana, A. E. G.; Bioresour. Technol. 2010, 101, 794; Freitas, M. C. R.; António, J. M. S.; Ziolli, R. L.; Yoshida, M. I.; Rey, N. A.; Diniz, R.; Polyhedron 2011, 30, 1922.

20. Zampini, I. C.; Vattuone, M. A.; Isla, M. I.; J. Ethnopharmacol. 2005, 102,450 .

21. Mukherjee, P. K.; Kumar,V.; Mal, M.; Houghton, P. J.; Phytomedicine 2007, 14, 289; Orhan, I.; Sener, B.; Choudhary, M. I.; Khalid, A.; $J$. Ethnopharmacol. 2004, 91, 57.

22. Howes, M. R.; Houghton, P. J.; Pharmacol. Biochem. Behav. 2003, 75, 513.

23. Balestrin, L.; Dias, J. F. G.; Miguel, O. G.; Dall'Stella, D. S. G.; Miguel, M. D.; Rev. Bras. Farmacog. 2008, 18, 230.

24. Mahato, S. B.; Kundu, A.; Phytochemistry 1994, 37, 1517.

25. Tanaka, R.; Tabuse, M.; Matsunaga, S.; Phytochemistry 1988, 27, 3563.

26. Tursch, B.; Leclercq, J.; Chiurdoglu, G.; Tetrahedron Lett. 1965, 47, 4161.

27. Korul'Kina, L. M.; Shul'ts, E. E.; Zhusupova, G. E.; Abilov, Z. A.;

Erzhanov, K. B.; Chaudri, M. I.; Chem. Nat. Prod. 2004, 40, 465.

28. Nawwar, M. A. M.; Ishak, M. S.; Michael, H. N.; Buddrus, J.; Phytochemistry 1984, 23, 2110; Agrawal, P. K.; Carbon-13 NMR of flavonoids; Elsevier: Amsterdam, 1989.

29. Abd El-Razek, M. H.; Asian J. Chem. 2007, 19, 4867.

30. Tung, N. H.; Ding, Y.; Kim, S. K.; Bae, K.; Kim, Y. H.; J. Agric. Food Chem. 2008, 56, 10510.

31. Sam, T. W. In Bioactive natural products: detection, isolation and structural determination; Colegate, S. M.; Molineux, R. J., eds.; CRC Press: Boca Raton, 1993.

32. CLSI - Clinical and Laboratory Standards Institute, Wayne: CLSI, 2005.

33. Mata, A. T.; Proença, C.; Ferreira, A. R.; Serralheiro, M. L. M.; Nogueira, J. M. F.; Araújo, M. E. M.; Food Chem. 2007, 103, 778.

34. Dias, M. O.; Hamerski, L.; Pinto, A. C.; Quim. Nova 2011, 34, 704.

35. Ikuta, A.; Itokawa, H.; J. Nat. Prod. 1989, 52, 623.

36. Foo, L. Y.; Lu, Y.; Molan, A. L.; Woodfield, D. R.; McNabb, W. C.; Phytochemistry 2000, 54, 539; Dat, N. T.; Cai, X. F.; Shen, Q.; Lee, I. S.; Kim, Y. H.; Chem Pharm. Bull. 2005, 53, 114.

37. Machado, K. E.; Cechinel Filho, V.; Tessarolo, R.; Mallmann, C.; Meyre-Silva, C.; Bella Cruz, A.; Pharm. Biol. 2005, 43, 636.

38. Rios, J. L.; Recio, M. C.; J. Ethnopharmacol. 2005, 100, 80.

39. Duffy, C. F.; Power, R. F.; Int. J. Antimicrob. Agents 2001, 17, 527; Kohler, T.; Pechere, J. C.; Plesiat, P.; Cell. Mol. Life Sci. 1999, 56, 771.

40. Orhan, I.; Kartal, M.; Tosun, F.; Sener, B.; Z. Naturforsch., C: J. Biosci. 2007, 62, 829.

41. Khan, M. T. H.; Orhan, I.; Senol, F. S.; Kartal, M.; Sener, B.; Dvorsk, M.; Smejkal, K.; Slapetov, T.; Chem. Biol. Interact. 2009, 181, 383.

42. Guo, A. J. Y.; Xie, H. Q.; Choi, R. C. Y.; Zheng, K. Y. Z.; Bi, C. W. C.; Xu, S. L.; Dong, T. T. X.; Tsim, K. W. K.; Chem. Biol. Interact. 2010, 187, 246

43. Yunes, R. A.; Pedrosa, R. C.; Cechinel Filho, V.; Quim. Nova 2001, 24, 147. 